\title{
EKSISTENSI INDUSTRI PIS BOLONG SEBAGAI MEDIA SOSIALISASI RELIGIUSITAS BUDAYA BALI BAGI WISATAWAN DI DESA KAMASAN, KLUNGKUNG
}

\author{
Putu Sabda Jayendra, I Wayan Eka Sudarmawan \\ Dosen Sekolah Tinggi Pariwisata Bali Internasional \\ sabda@stpbi.ac.id, ekasdr@stpbi.ac.id
}

\begin{abstract}
Tourism in Bali is dominated by cultural tourism inspired by the religiosity of Hinduism. The potential of Balinese religion and culture gives birth to many cultural products that become excellent tourist destinations. In this case, Kamasan Village, located in Klungkung Subdistrict, Klungkung Regency, has one of the mainstay products in the form of pis bolong (Uang Kepeng). The perforated industry in the village of Kamasan in this case is not only a tourist attraction, but also as a medium to socialize the religiosity of Balinese culture for tourists. In this case, tourists not only enjoy the destination, but also learn about religious and magical Balinese culture. This is very important to be studied in the midst of the massive phenomena of the degradation of the Balinese people's understanding of cultural religiosity, one of which is caused by the widespread circulation of imitation pis which is not in accordance with the religious principles of Balinese culture.
\end{abstract}

Keywords: pis bolong, religious, Kamasan village.

\section{A. PENDAHULUAN}

Dinamika pariwisata di Bali sangat dominan dikonstruksi dari aspek kebudayaan. Terlebih budaya Bali merupakan salah satu budaya yang memiliki religiusitas yang sangat tinggi. Hal disebabkan mayoritas masyarakat Bali yang memeluk Agama Hindu mampu memadukan unsur budaya dan agama dengan sangat apik, sehingga seolah antara Agama Hindu dan budaya Bali sudah menjadi satu kesatuan yang tidak terpisahkan satu sama lain. Hal inilah yang menjadi salah satu alasan para wisatawan asing, baik domestik maupun mancanegara memiliki ketertarikan untuk melihat, mengamati, bahkan mempelajari secara lebih mendalam tentang budaya Bali.

Kodhyat (dalam Sumadi, 2012:11) menyatakan bahwa pada awal perkembangan pariwisata di dunia memang ditandai dengan aktivitas perjalanan atau petualangan seseorang ke tempat-tempat yang disenangi dengan berbagai tujuan, seperti melaksanakan ibadah agama, perdagangan, memenuhi rasa ingin tahu, tujuan rekreasi, melaksanakan suatu misi, atau tujuan edukatif. Terkait dengan hal tersebut, pariwisata di Bali tidak semata-mata bertujuan hanya menjadi ajang promosi, namun juga mensosialisasikan sekaligus mengedukasi para wisatawan tentang seluk-beluk budaya Bali yang bersifat religius. Peraturan Daerah Bali No. 3 Tahun 1974 yang telah diperbaharui menjadi Perda No. 3 Tahun 1991 menjelaskan; Kepariwisataan yang dikembangkan di Bali adalah "Pariwisata Budaya", satu jenis kepariwisataan yang bertumpu pada kebudayaan Bali yang dijiwai Agama Hindu. Dalam pasal 1 ditegaskan Pariwisata Budaya adalah jenis kepariwisataan yang dalam perkembangan dan 
pengembangannya menggunakan Kebudayaan Daerah Bali yang dijiwai oleh Agama Hindu yang merupakan bagian dari kebudayaan nasional sebagai potensi dasar yang dominan, yang di dalamnya tersirat satu cita-cita akan adanya hubungan timbal balik antara pariwisata dan kebudayaan sehingga keduanya meningkat secara serasi, selaras, dan seimbang. Berlandaskan hal tersebut, beberapa desa di Bali yang memiliki destinasi budaya religius yang khas dan kreativitas yang tinggi dalam konsep pelestarian budayanya telah ditetapkan berpredikat Desa Wisata.

Salah satunya adalah Desa Kamasan yang terletak di Kecamatan Klungkung, Kabupaten Klungkung, Bali. Desa Kamasan merupakan salah satu desa yang telah ditetapkan sebagai desa yang berpredikat desa wisata oleh pemerintah daerah Kabupaten Klungkung, dan bahkan hingga saat ini merupakan desa binaan BNI. Desa Kamasan merupakan salah satu desa wisata yang bertumpu pada potensi seni budaya Bali yang dijiwai religiusitas Agama Hindu yang tinggi. Beberapa produk budaya terkenal dari Desa Kamasan antara lain kerajinan perak, lukisan wayang, dan industri kerajinan pis bolong (uang kepeng).

Pis bolong atau uang kepeng merupakan salah satu produk kebudayaan yang memiliki nilai religiusitas di Bali. Umat Hindu di Bali mempergunakan pis bolong sebagai sarana upacara dan upakara dalam menjalankan aktivitas ritual keagamaannya. Pis bolong pada masyarakat Bali adalah salah satu simbol kemakmuran dan saat ini masih sangat banyak digunakan dalam upacara keagamaan Hindu (Astiti, 2014:45). Disamping itu, pis bolong memiliki nilai historis serta estetika yang tinggi, sehingga menjadi banyak diburu oleh para kolektor, yang juga terdiri dari wisatawan asing. Fenomena tersebut membuat keberadaan pis bolong asli mulai langka keberadaannya, disamping harganya yang cenderung tinggi akibat kelangkaan tersebut. Fenomena tersebut ditunjang oleh sikap masyarakat Bali yang mulai menerapkan cara-cara praktis dan efisien dalam menyikapi permasalahan tersebut.

Dampaknya adalah munculnya pembuatan pis bolong imitasi secara masif, dimana sangat jauh berbeda dibandingkan dengan pis bolong asli, baik dari segi bahannya, kualitasnya dan nilai estetikanya. Fenomena ini menimbulkan kecenderungan pula akan pemaknaan religiusitas budaya Bali melalui media pis bolong akan mengalami pergeseran ke arah sekuler, dan membuat pola pikir yang apatis, karena kehadiran pis bolong hanya dianggap sekedar sarana pelengkap dalam upacara dengan mengabaikan aspek filosofisnya. Uang kepeng atau pis bolong merupakan salah satu budaya lokal yang berada ditengah era globalisasi dan perkembangan industri pariwisata di Bali (Arisanti, 2015:4). Beranjak dari hal tersebut, eksistensi industri pis bolong di Desa Kamasan tidak hanya memiliki visi dan misi untuk sekedar memasarkan pis bolong sebagai produk budaya semata, namun juga memiliki visi dan misi membuat, melestarikan, dan membelajarkan filosofi pis bolong asli kepada masyarakat lokal dan wisatawan asing.

Pis bolong yang dikembangkan di Desa Kamasan dominan berbahan lima jenis logam yang disebut Panca Datu. Di Desa Kamasan, pengrajin pis bolong yang paling menonjol dan terkenal akan karyanya adalah UD Kamasan Bali, disamping beberapa pengrajin lainnya, seperti pengrajin Taksu Agung yang didirikan oleh Bapak I Gede Surya Atmaja, dan beberapa pengrajin rumahan lainnya. Industri kerajinan pis bolong diinisiasi mengingat kelangkaan pis bolong yang asli, karena pis bolong asli merupakan produksi dari jaman kerajaan Cina. Menurut Widana dan Sulistyawati (dalam Arisanti, 2015:4), uang kepeng Cina diperkirakan mulai beredar Bali sekitar abad ke tujuh Masehi sebagai alat pembayaran. Lambat laun uang kepeng mulai mengalami 
pergeseran fungsi, dimana seiring perkembangan zaman, dungsi uang kepeng tidak lagi sebagai uang kartal (Sudarma, 2016:13).

Berdasarkan hal tersebut, maka penting dan menarik untuk ditelusuri tentang eksistensi industri pis bolong di Desa Kamasan, mencakup jenis pis bolong yang serta pola-pola sosialisasi yang dilakukan kepada wisatawan. Urgensi penelitian ini dilakukan mengingat pentingnya pemahaman akan religiusitas budaya Bali secara menyeluruh dan mendalam, yang dalam hal ini sasarannya adalah wisatawan asing dalam rangka membangun citra pariwisata budaya Bali yang positif. Melalui hasil penelitian ini, diharapkan pula dapat menjadi salah satu sumbangan pemikiran dalam pengembangan pariwisata budaya Bali yang inovatif dan berkelanjutan.

\section{B. PEMBAHASAN}

\section{Pis Bolong Yang Dikembangkan di Desa Kamasan}

Pis bolong sebagai salah satu produk budaya yang paling ikonik di Desa Kamasan sudah sangat terkenal sebagai sentra pengrajin pis bolong yang asli. Pis bolong yang dikembangkan di Desa Kamasan umumnya dapat diklasifikasikan menurut bahan, motif, dan kegunaannya. Adapun klasifikasi tersebut dapat dijelaskan sebagai berikut.

a) Klasifikasi menurut bahan pembuatan pis bolong.

Menurut bahan pembuatannya, maka pis bolong yang diproduksi di Desa Kamasan dapat dibedakan menjadi dua jenis, yakni pis bolong yang berbahan Panca Datu dan pis bolong yang berbahan Tri Datu. Pis bolong berbahan Panca Datu, yakni memadukan lima unsur logam yang terdiri dari; (1) Besi dengan rumus kimianya Fe, melambangkan kekuatan Dewa Wisnu, berwarna hitam, dan menempati posisi arah Utara, (2) Perak dengan rumus kimianya Ag, melambangkan kekuatan Dewa Iswara, berwarna putih, dan menempati posisi arah Timur, (3) Tembaga dengan rumus kimianya $\mathrm{Cu}$, melambangkan kekuatan Dewa Brahma, berwarna merah, menempati posisi arah Selatan, (4) Emas dengan rumus kimianya $\mathrm{Au}$, melambangkan kekuatan Dewa Mahadewa, berwarna kuning, menempati posisi arah Barat dan, (5) Kuningan dengan unsur kimianya CuZn, melambangkan kekuatan Dewa Siwa, berwarna-warni (mancawarna), menempati posisi arah Tengah, sebagai poros atau pusat alam semesta. Kelima komponen logam tersebut dicampur dengan komposisi 25\% tembaga, 50\% kuningan, $15 \%$ timah, $1 \%$ emas, perak, dan besi, serta sebagai logam penguat dipergunakan 9\% aluminium. Sedangkan pis bolong berbahan Tri Datu memiliki bahan yang sama dengan pis bolong berbahan Panca Datu, hanya saja tanpa bahan emas dan perak, sehingga unsur aluminiumnya yang diperbanyak.

\section{b) Klasifikasi menurut motif pis bolong}

Selain menurut bahan atau komponen pembuatannya, pis bolong yang dikembangkan di Desa Kamasan juga dapat diklasifikasikan menurut motifnya. Secara garis besar terdapat dua motif utama yang diukirkan pada pis bolong, yaitu ukiran aksara Bali dan motif ukiran wayang. Motif aksara Bali yang diukirkan pada pis bolong mengacu pada pedoman baku yang disepakati oleh pemerintah, pemuka agama dan masyarakat umum yang tergabung dalam lembaga Bali Heritage Trust. Pemerintah Daerah Bali melalui SK Gubernur No. 68 Tahun 2003, membentuk Bali Heritage Trust, lembaga yang bertugas melakukan upaya-upaya pelestarian budaya Bali. Bali Heritage Trust dan beberapa komponen masyarakat Bali yang peduli dengan pelestarian pis bolong atau uang kepeng mendesainnya sesuai dengan budaya Bali. Kegiatan ini juga 
didukung oleh Gubernur Bali yang menyadari kondisi bahwa pis bolong asli yang berasal dari Cina, kini sudah tidak diproduksi lagi di Cina. Untuk itu perlu dilakukan upaya reproduksi pis bolong yang memegang peranan penting dalam ritual agama Hindu di Bali. Terlebih dengan muncul dan maraknya peredaran pis bolong dengan bahan seng tipis dan ukiran aksara yang tidak jelas, sehingga dianggap tidak sesuai dengan filosofi budaya Bali yang religius. Untuk memberikan gambaran tentang pis bolong yang asli berasal dari Cina, maka dapat dilihat ada gambar berikut.

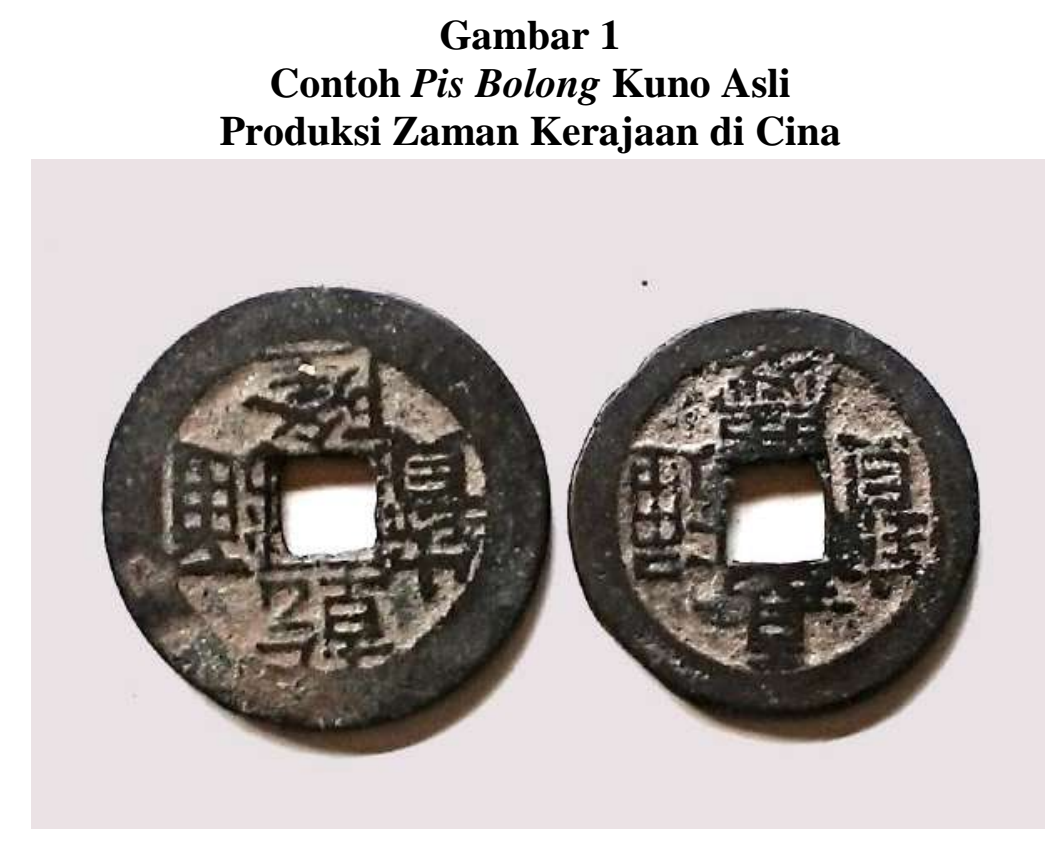

(Sumber: Dokumentasi Jayendra, 2018).

Berdasarkan gambar tersebut, pis bolong yang asli dan lazim dipergunakan pada zaman dahulu adalah pis bolong yang berasal dari Cina. Disamping dari ketebalan bahan dan kerumitan aksara-aksara Cina yang terukir dalam pis bolong tersebut, faktor keaslian atau keotentikannya menjadi dasar pertimbangan penggunaannya dalam setiap upacara yadnya dikalangan umat Hindu, khususnya di Bali. Berkaitan dengan hal tersebut, Lembaga Bali Heritage Trust yang berada dibawah Dinas Kebudayaan Provinsi Bali, dengan dimotori oleh Ida Pedanda Made Gunung (alm) menyepakati huruf universal pada bagian depan pis bolong Panca Datu yaitu aksara suci $S a, B a, T a$, $A, I$. Sedangkan di sisi belakang pis bolong tersebut disepakati aksara suci Ang dan Ah. Untuk memberikan mengenai aksara Bali dalam pis bolong tersebut, maka dapat dilihat dalam gambar berikut. 


\section{Gambar 2 \\ Pis Bolong Panca Datu Dengan Aksara Bali Produksi Desa Kamasan}

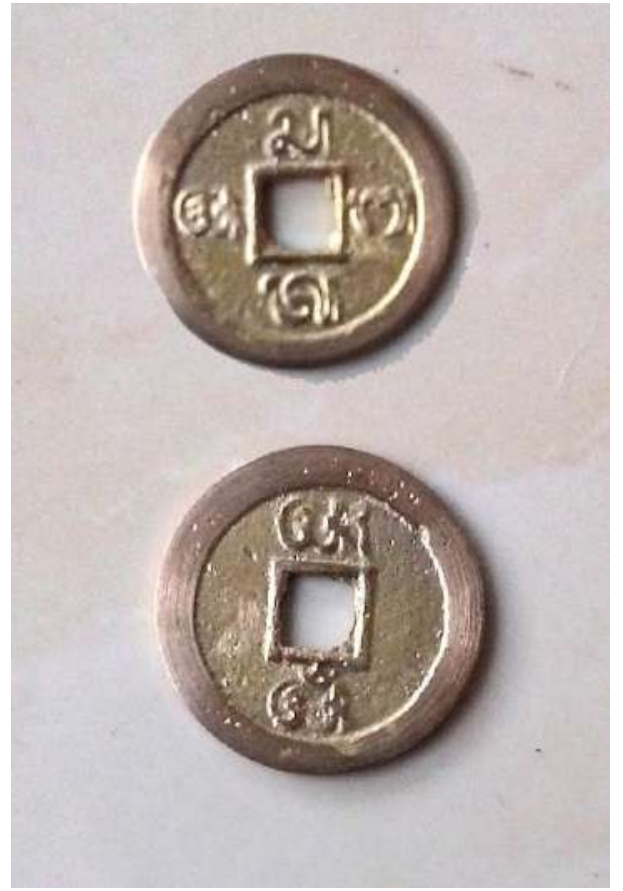

(Sumber: dokumentasi Jayendra, 2018).

Aksara Bali yang diukirkan tersebut memiliki arti yang bersifat religius magis bagi masyarakat Hindu Bali. Aksara-aksara suci yang menjadi filosofi dasar dari pis bolong ini memiliki makna sebagai berikut.

1. Sa merupakan aksara suci yang merupakan singkatan dari Sadhyojata, yakni nama Dewa Penguasa Alam Timur, yaitu Dewa Iswara.

2. Aksara Ba merupakan singkatan dari Bamadéwa, yakni Dewa Penguasa Alam Selatan yaitu Dewa Brahma.

3. Aksara Ta merupakan singkatan dari Tatpurusa, yakni Dewa Penguasa Alam Barat, yaitu Dewa Mahadewa.

4. Aksara A merupakan singkatan dari Aghora, yakni Dewa Penguasa Alam Utara, yaitu Dewa Wisnu.

5. Aksara I merupakan singkatan dari Isana, yakni Dewa Penguasa Alam Tengah, yaitu Dewa Siwa.

Aksara I tidak terukir pada pis bolong, karena letaknya di tengah-tengah bagian yang bolong atau berlubang, karena merupakan poros bhuwana atau pusatnya jagat. Namun demikian, kelima aksara tersebut, yang disebut sebagai Panca Aksara tetap dianggap satu kesatuan pada pis bolong. Aksara suci itu berhubungan dengan filsafat Hindu, terutama aliran Siwa (Bagus dalam Suarka, 2009:8).

Sedangkan motif pis bolong yang motif wayang merupakan hasil pengembangan dan kreativitas dari pengrajin. Dalam hal ini UD Kamasan Bali merupakan satusatunya pengrajin yang memproduksi pis bolong jenis ini. Motif wayang sesungguhnya telah ada sejak zaman dahulu, yang kebanyakan berfungsi sebagai jimat atau dipercaya memiliki tuah tertentu, misalnya pis bolong Rejuna (pis bolong dengan motif wayang gambar Arjuna) yang dipercaya mampu memberikan efek bagi pria 
yang membawanya untuk memikat lawan jenis. Kepercayaan ini masih berkembang hingga saat ini di Bali. Melihat hal inilah maka UD Kamasan Bali mengembangkan pis bolong jenis ini dengan maksud untuk hiasan atau souvenir. Adapun contohnya dapat dilihat dalam gambar berikut.

\section{Gambar 3 \\ Pis Bolong Dengan Motif Wayang Bhatara Rambut Sedana Sebagai Simbol Pembawa Rejeki}

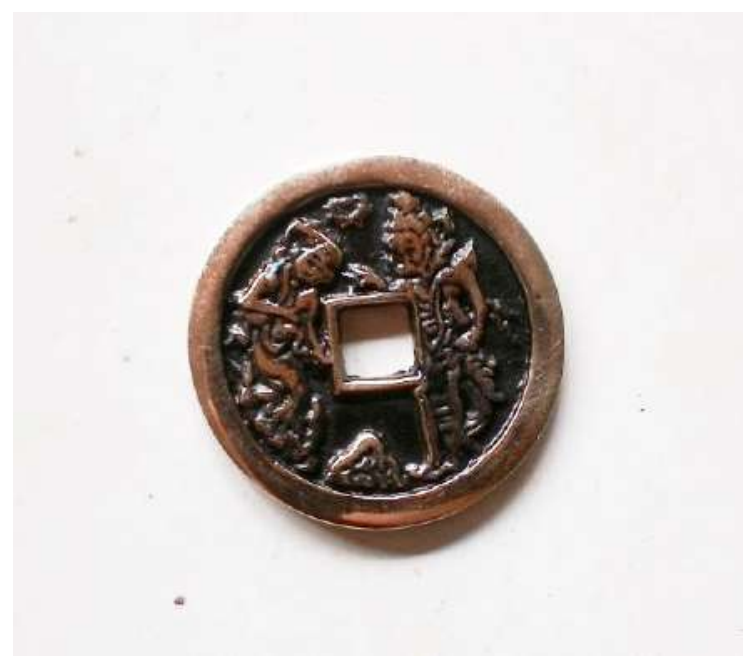

(Sumber: Dokumentasi Jayendra, 2018).

Pis bolong dengan motif wayang memiliki bahan dasar yang sama dengan jenis pis bolong motif aksara, yaitu Panca Datu. Perbedaannya adalah apabila pis bolong yang bermotif aksara mempergunakan alat pencetak untuk mengukirkan aksara-aksara Bali tersebut, maka pis bolong yang bermotif wayang mempergunakan keterampilan tangan untuk mengukirkan motifnya. Disinilah dituntut kejelian dan presisi yang tinggi dalam tiap individu pengrajin yang membuatnya hingga menghasilkan produk seni yang berkualitas dan memiliki nilai estetika yang sangat tinggi. Selain itu, pis bolong yang bermotif wayang memiliki ketebalan yang lebih daripada pis bolong motif aksara Bali, dan diameternya juga sedikit lebih besar. Oleh karena pembuatannya yang sangat rumit, maka harganyapun jauh lebih mahal daripada pis bolong aksara Bali. Berdasarkan hasil observasi tahun 2018, harga pis bolong motif aksara Bali adalah Rp. 1.500,- per keping, sedangkan harga pis bolong bermotif ukiran wayang adalah Rp. 50.000,- per kepingnya.

c) Klasifikasi menurut tujuan penggunaan pis bolong.

Pis bolong yang dikembangkan di Desa Kamasan apabila diklasifikasikan berdasarkan tujuan penggunaannya, maka dapat dibagi menjadi dua, yakni untuk tujuan upacara keagamaan dan untuk souvenir. Sebagaimana yang telah dijelaskan sebelumnya bahwa pis bolong yang dibuat untuk tujuan upacara keagamaan Hindu di Bali dpergunakan yang bermotif aksara Bali. Hanya saja dibedakan jenis upacaranya menurut bahan pembuatan pis bolong tersebut. Pis bolong yang mempergunakan bahan Panca Datu, merupakan jenis yang multifungsi dan paling banyak dicari oleh konsumen yang beragama Hindu. selain dapat dipergunakan untuk persembahyangan dan upacara- 
upacara Yadnya, pis bolong motif aksara Bali berbahan Panca Datu juga khusus dipergunakan untuk ritual mendem (pemenaman atau penanaman), yang biasanya dilakukan umat Hindu di Bali saat mengawali membuat bangunan, baik bangunan tempat tinggal maupun tempat suci atau palinggih. Tujuannya adalah agar mendapatkan keharmonisan dan sebagai simbol pengajeg jagat. Sedangkan pis bolong motif aksara Bali berbahan Tri Datu memiliki fungsi yang sama dengan pis bolong motif aksara Bali berbahan Panca Datu, hanya saja tidak dapat digunakan untuk ritual mendem.

Penggunaan unsur Panca Datu dalam ritual pemendeman ini dilatarbelakangi dari peristiwa Rsi Markandya yang memasuki Pulau Bali bersama pengiringnya sebanyak 800 orang dari Jawa Timur, yang menurut Nurkancana (2009:130) peristiwa ini terjadi pada Tahun Saka 85 atau 163 Masehi. Pada saat itu Pulau Bali masih berupa hutan yang sangat lebat dan angker, sehingga mereka bermaksud merabasnya untuk membangun pemukiman. Namun terjadi musibah beruntun yang menyebabkan banyaknya pengiring Maharsi Markandya meninggal dunia, sehingga mereka memutuskan untuk kembali pulang ke Jawa Timur.

Kembalinya Maharsi Markandya ke pasraman beliau di Gunung Raung, Jawa Timur adalah untuk melakukan yoga samadhi dengan tujuan mengetahui sebabnya bencana yang menimpa para pengiringnya. Akhirnya beliau mendapatkan pawisik bahwa terjadinya bencana itu karena beliau tidak melaksanakan upacara keagamaan sebelum membuka hutan itu (Wikarman, 1998:16)

Maharsi Markandya datang lagi ke Bali dengan pengiring sebanyak 400 orang. Kedatangan mereka untuk yang kedua kalinya berhasil dikarenakan Maharsi Markandya bersama pengiringnya telah melaksanakan upacara atau ritual sebelum menerabas hutan, serta melakukan penanaman Panca Datu. Tempat penanaman Panca Datu tersebut dinamai Besuki, yang kemudian menjadi Besakih yang artinya selamat (Wikarman, 1998:16). Peristiwa tersebut menjadi acuan bagi masyarakat Hindu Bali hingga saat ini dimana saat mulai membangun tempat suci atau bangunan suci (palinggih), dan bangunan-bangunan lainnya, wajib melaksanakan pemendeman pedagingan disertai dengan penanaman Panca Datu sebagai simbol pengurip-urip dan kestabilan jagat.

Sedangkan tujuan penggunaan pis bolong untuk souvenir ini didominasi oleh pis bolong yang mempergunakan motif ukiran wayang. Selain karena memiliki nilai estetika yang tinggi, pis bolong motif ukiran wayang ini dipercaya mampu membawa tuah atau manfaat tertentu bagi yang membawanya. Beberapa contoh diantaranya adalah:

1. Motif Dewata Nawa Sangha, dipahami secara umum merupakan simbol kekuatan dewa yang menempati sembilan arah penjuru mata angin.

2. Motif Dewi Saraswati, dipahami sebagai manifestasi Ida Sang Hyang Widhi Wasa, sakti dari Dewa Brahma sebagai sumber dari segala ilmu pengetahuan.

3. Motif Arjuna (dikenal pula dengan nama Pis bolong Rejuna), dipahami sebagai salah satu tokoh Pandawa dalam kisah Mahabharata yang paling sakti dan tampan. Apabila pis bolong ini dibawa, diharapkan aura ketampanan akan terpancar dari pemakainya.

4. Motif Hanuman, dipahami sebagai kera putih, tokoh pewayangan yang sangat terkenal dalam epos Ramayana. Hanuman dipahami sebagai pengikut yang paling setia dari Sri Rama.

5. Motif Bhatara Rambut Sedana, dipahami sebagai Dewa Kekayaan dan pemberi rezeki. Apabila pis bolong ini dibawa dan disimpan, diharapkan dapat melancarkan rejeki pemiliknya. 
6. dan lain-lain.

Terkait dengan hal tersebut, pihak UD Kamasan Bali yang melirik tingginya minat wisatawan, baik lokal, domestik, maupun mancanegara terhadap hal tersebut membuat suatu inovasi dengan membuat liontin pis bolong. Pis bolong yang dikembangkan menjadi liontin adalah pis bolong yang memiliki motif ukiran wayang. Hal ini dilakukan agar tampilan pis bolong semakin menarik dengan dipergunakan pada rantai kalung. Adapun contoh produknya dapat dilikat pada gambar berikut.

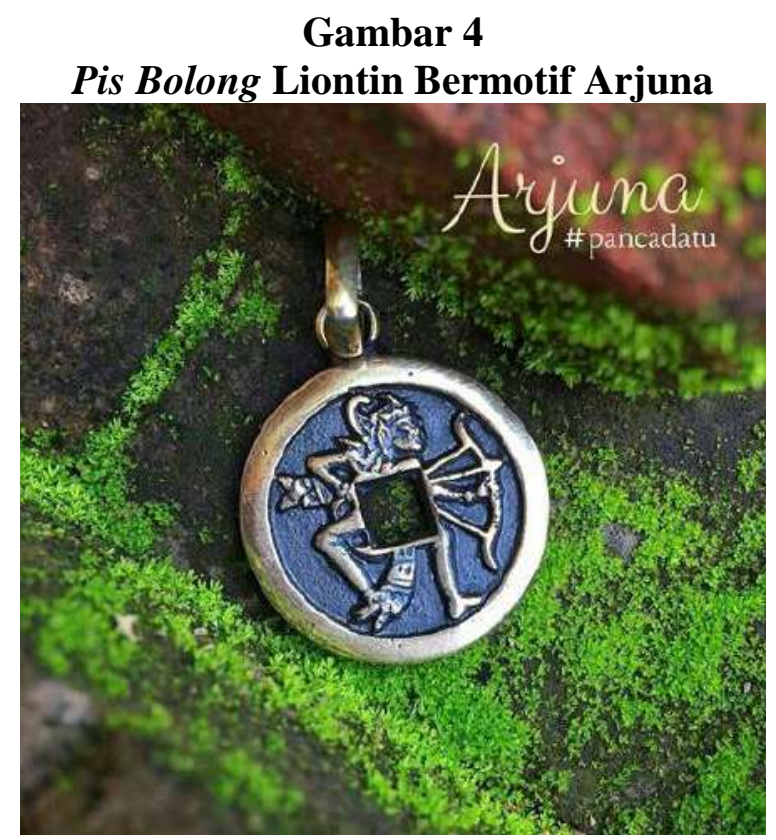

(Sumber: Instagram kamasanbali, 2018).

Pis bolong yang dimodifikasi menjadi liontin ini merupakan salah satu souvenir yang paling banyak diminati oleh wisatawan asing. Minat yang tinggi inilah yang membuat para wisatawan berdatangan ke Desa Kamasan, terutama pengrajin di UD Kamasan Bali. Melihat tingginya antusiasme wisatawan inilah yang dimanfaatkan oleh pihak UD Kamasan Bali, yakni tidak hanya sebatas memasarkan produk, namun juga mensosialisasikan sekaligus mengedukasi tentang nilai-nilai religiusitas budaya Bali.

\section{Pola-pola Sosialisasi Religiusitas Budaya Bali Melalui Media Pis Bolong}

Tingginya antusiasme terhadap produk-produk pis bolong produksi Desa Kamasan menjadi salah satu faktor mudahnya mensosialisasikan dan mengedukasi wisatawan asing mengenai religiusitas budaya Bali yang dijiwai oleh agama Hindu. Ketertarikan dan minat yang tinggi secara tidak langsung membuat pemahaman wisatawan menjadi lebih terbuka (open mind), terlebih banyak pula wisatawan yang berlatar belakang pelajar atau mahasiswa datang dengan maksud untuk belajar (study) mengenai seluk beluk pis bolong beserta peran pentingnya dalam kebudayaan Hindu Bali yang religius. Tujuannya dari hal ini adalah untuk menanamkan respect yang setinggi-tingginya dalam diri para wisatawan terhadap religiusitas budaya Bali. Terkait dengan hal tersebut, adapun pola-pola sosialisasi yang dilakukan dapat dijabarkan sebagai berikut. 


\section{a. Pemanfaatan Media Sosial Instagram}

Pemanfaatan media sosial Instagram sebagai sarana untuk mempromosikan kerajinan pis bolong produksi Desa Kamasan merupakan suatu pola strategis yang memiliki banyak kelebihan. Pertama, media sosial mampu mempersempit jarak antara ruang dan waktu serta menghemat tenaga untuk menjelaskan mengenai fungsi dan makna pis bolong bagi wisatawan. Wisatawan, baik lokal, domestik, maupun mancanegara dari berbagai wilayah dapat mengakses Instagram resmi dari UD Kamasan Bali dengan sangat mudah, yakni dengan mem-follow nama Instagram "kamasanbali". Kedua, media sosial Instagram sekaligus juga menjadi ajang promosi dan pemasaran produk-produk UD Kamasan Bali yang sarat akan filosofi makna yang religius, sehingga menarik minat wisatawan dengan sangat mudah dan praktis, sehingga nama Desa Kamasan semakin dikenal sebagai sentra penghasil kerajinan pis bolong di Bali.

Media sosial Instagram dipilih karena dinilai mampu memuat media foto atau gambar secara khusus dengan kualitas yang sangat baik. Foto atau gambar yang ditampilkan diisi penjelasan singkat tentang makna pis bolong yang ditampilkan. Adapun pemanfaatan media sosial Instagram oleh UD Kamasan Bali sebagai ajang promosi sekaligus sosialisasi budaya Bali melalui pis bolong dapat dilihat dalam contoh gambar berikut.

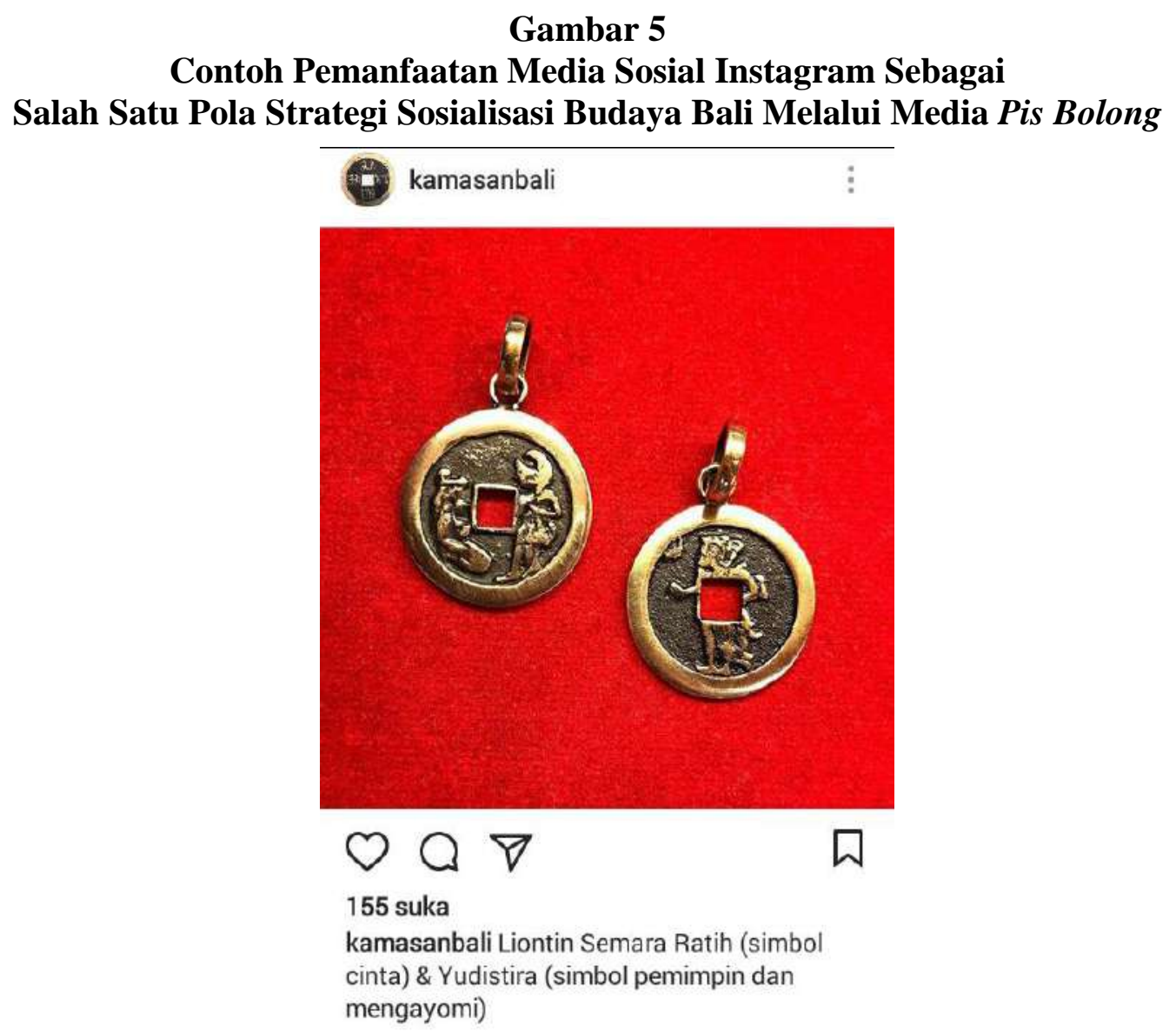

(Sumber: Instagram kamasanbali, 2018).

Melalui gambar dan penjelasan singkat yang diunggah lewat media sosial Instagram, para wisatawan yang berminat akan bertanya lebih lanjut mengenai filosofi 
motif pis bolong melalui kolom komentar jika ada hal-hal yang dirasa kurang jelas. Hanya saja jika ada yang berminat untuk memesan, maka pembelian hanya dapat dilakukan dengan datang langsung ke lokasi UD Kamasan Bali. Meskipun demikian, sosialisasi yang dilakukan melalui media sosial Instagram ini telah mampu memberikan pengetahuan mengenai dasar-dasar religiusitas budaya Bali lewat promosi produk pis bolong dengan tidak terbatas pada tempat dan waktu.

\section{b. Melalui Kunjungan Langsung Wisatawan}

Pola sosialisasi yang kedua adalah melalui kunjungan langsung dari wisatawan yang datang ke UD Kamasan, yang umumnya hampir terjadi setiap hari pada jam buka. Menurut penjelasan dari Bapak I Made Sukma Swacita (wawancara tanggal 27 Juni 2018), umumnya wisatawan yang sudah mengetahui keberadaan UD Kamasan Bali melalui media sosial akan datang ke lokasi melalui request kepada pihak Travel yang akan memfasilitasi perjalanan mereka. Atau bisa juga pihak Travel yang menawarkan paket perjalanan yang salah satunya berkunjung ke Desa Kamasan untuk melihat dan belajar mengenai industri pis bolong dengan segala filosofinya yang religius.

Untuk itu, pihak Travel perjalanan wisata akan menghubungi pihak UD Kamasan Bali via telepon untuk menanyakan apakah hari itu buka atau tutup. Apabila buka maka perjalanan akan dilakukan ke lokasi. Sesampainya di lokasi, pemilik UD Kamasan yang berkolaborasi dengan guide yang disiapkan oleh agen Travel perjalanan wisata akan memberikan penjelasan tentang makna filosofis pis bolong yang menjadi dasar dari religiusitas budaya Hindu Bali. Untuk memudahkan dalam memahami kegiatan tersebut dapat dilihat melalui gambar berikut.

\section{Gambar 6}

\section{Wisatawan Yang Berkunjung Mendapat Sosialisasi Tentang Religiusitas Budaya Bali Langsung Dari Pemilik UD Kamasan Bali Bapak I Made Sukma Swacita}

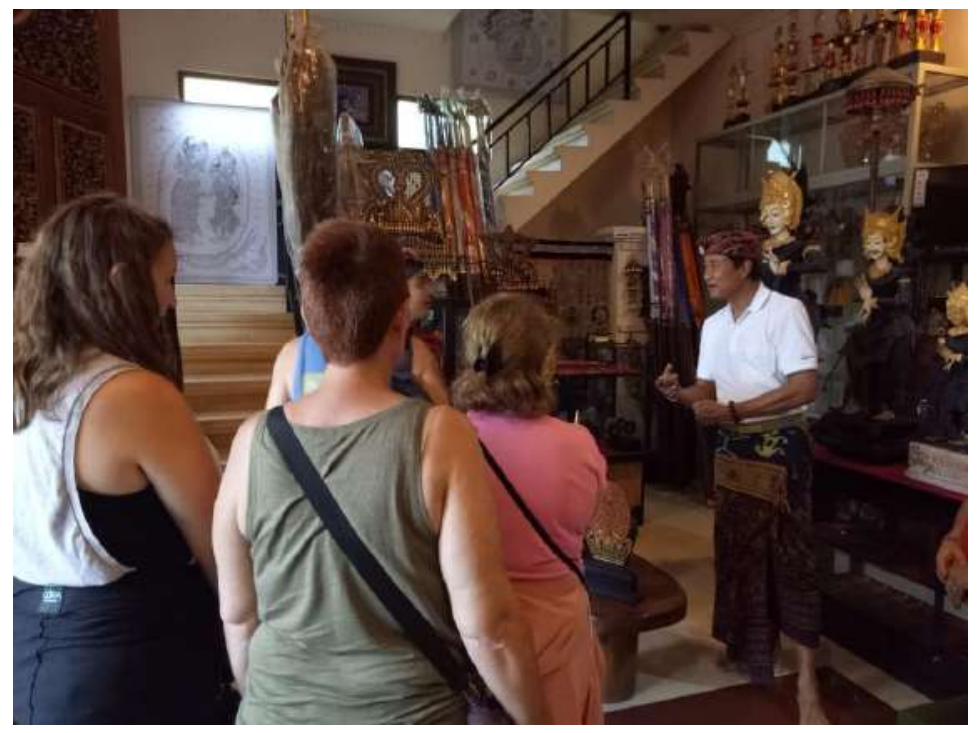

(Sumber: Dokumentasi Jayendra, 2018). 


\section{Gambar 7}

\section{Para Wisatawan Mendapat Penjelasan Tentang Makna Filosofis Pis Bolong Dari Guide Yang Berkolaborasi Dengan Pihak UD Kamasan Bali}

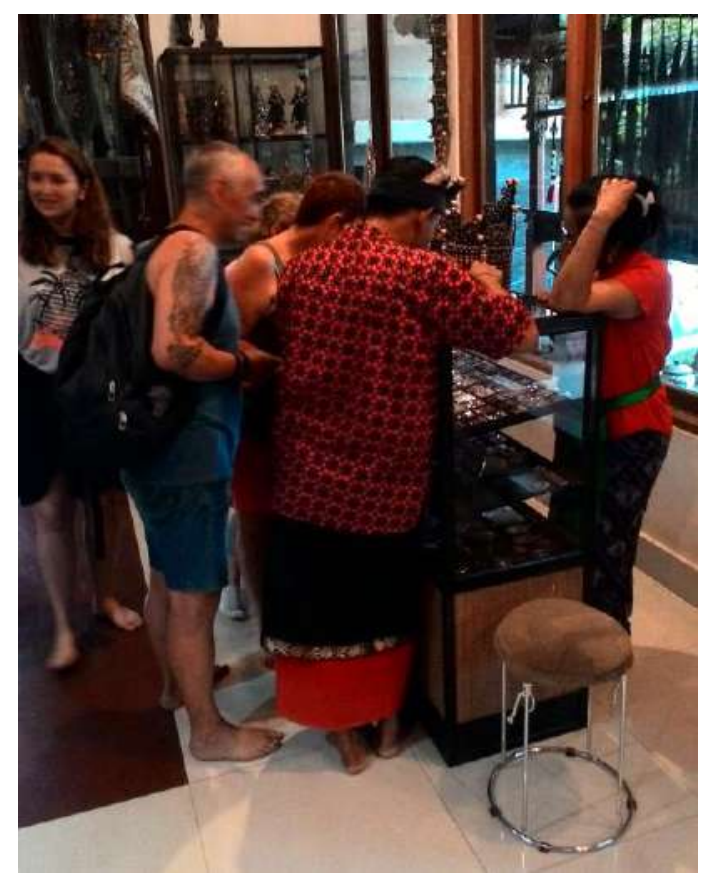

(Sumber: Dokumentasi Sudarmawan, 2018).

Melalui gambar tersebut di atas, dapat dianaliis bahwa pis bolong memiliki daya tarik tersendiri yang membuat wisatawan termotivasi untuk belajar lebih banyak tentang religiusitas budaya Bali. dalam hal ini, pis bolong merupakan komoditi yang tidak hanya terbatas pada sumber daya untuk menggerakkan roda perekonomian Desa Kamasan. Lebih dari itu, yang terpenting adalah mampu mengedukasi para wisatawan yang datang ke Bali, khususnya Desa Kamasan bagaimana respect terhadap budaya Bali yang religius. Hal ini senada dengan isi Teori Fungsional Struktural dari Parsons (dalam Ritzer, 2014:117-118) yang menyatakan bahwa sistem kepribadian melaksanakan fungsi pencapaian tujuan dengan menetapkan tujuan sistem dan memobilisasi sumber daya yang ada untuk mencapainya.

Berkenaan dengan hal tersebut, wawancara dengan I Made Sukma Swacita menyatakan bahwa peluang ke depannya untuk lebih mengoptimalkan sosialisasi religiusitas budaya Bali melalui pis bolong adalah dengan menyediakan fasilitas berupa home stay sebagai tempat wisatawan menginap beberapa hari agar dapat secara khusus meneliti dan terlibat langsung dengan proses produksi kerajinan pis bolong. Wacana ini muncul sebagai apresiasi tingginya minat wisatawan yang ingin belajar dan masukanmasukan dari berbagai pihak, utamanya pihak Desa Kamasan sendiri, dan juga dari Pemerintah Kabupaten Klungkung. Melalui pola-pola sosialisasi yang diaplikasikan melalui media pis bolong, diharapkan pemahaman wisatawan akan semakin mendalam berkenaan dengan religiusitas budaya Bali yang dijiwai oleh agama Hindu. 


\section{PENUTUP}

\section{Simpulan}

Eksistensi industri pis bolong atau uang kepeng di Desa Kamasan, Klungkung di latar belakangi oleh kelangkaan pis bolong asli, karena pis bolong asli berasal dari zaman kerajaan-kerajaan di Cina, sehingga sudah tidak lagi diproduksi. Hal ini memicu diciptakannya pis bolong imitasi yang terbuat dari bahan seng tipis. Namun pis bolong imitasi tersebut dirasa tidak sesuai dengan pakem filosofis religiusitas Hindu Bali, baik dari segi aspek bahan, maupun motif atau ukiran-ukirannya. Hal inilah yang memelopori terjadinya kesepakatan antara pemerintah, pemuka agama, dan masyarakat umum melalui Bali Heritage Trust.

Melalui SK Gubernur No. 68 Tahun 2003, membentuk Bali Heritage Trust, lembaga yang bertugas melakukan upaya-upaya pelestarian budaya Bali. Bali Heritage Trust dan beberapa komponen masyarakat Bali yang peduli dengan pelestarian pis bolong atau uang kepeng mendesainnya sesuai dengan budaya Bali. Implikasinya adalah permintaan akan pis bolong menjadi cukup tinggi. Eksistensi industri kerajinan pis bolong di Desa Kamasan kemudian semakin diperkuat pula dengan adanya minat wisatawan, baik yang berasal dari daerah Bali sendiri, maupun wisatawan domestik dan juga wisatawan mancanegara. Hal ini mendorong pengrajin pis bolong di Desa Kamasan untuk semakin inovatif dalam karya-karyanya.

Pola sosialisasi religiusitas budaya Bali melalui media pis bolong bagi wisatawan di Desa Kamasan dilakukan dengan dua cara, yakni sosialisasi melalui media sosial Instagram dan memanfaatkan kunjungan langsung dari wisatawan. Media sosial mampu mempersempit jarak antara ruang dan waktu serta menghemat tenaga untuk menjelaskan mengenai fungsi dan makna pis bolong bagi wisatawan. Media sosial Instagram sekaligus juga menjadi ajang promosi dan pemasaran produk-produk kerajinan pis bolong yang sarat akan filosofi makna yang religius, sehingga menarik minat wisatawan dengan sangat mudah dan praktis. Pola kedua melalui kunjungan langsung dari wisatawan yang datang ke UD Kamasan, umumnya hampir terjadi setiap hari pada jam buka. Umumnya wisatawan yang sudah mengetahui keberadaan UD Kamasan Bali melalui media sosial akan datang ke lokasi melalui request kepada pihak Travel yang akan memfasilitasi perjalanan mereka. Atau bisa juga pihak Travel yang menawarkan paket perjalanan yang salah satunya berkunjung ke Desa Kamasan untuk melihat dan belajar mengenai industri pis bolong dengan segala filosofinya yang religius.

\section{Saran}

Sebagai penutup, maka dapat disarankan beberapa hal sebagai berikut. Pertama, kepada pihak pemerintah agar senantiasa memberikan support yang intensif kepada aset-aset budaya Bali, agar senantiasa berinovasi dan mampu menjadi potensi pariwisata andalan yang ikonik dan berbasis budaya. Kedua, kepada generasi muda hendaknya berperan aktif dalam melestarikan, mengeksplorasi, serta berinovasi terhadap potensipotensi budaya lokal agar mampu dikembangkan sebagai aset yang memiliki nilai untuk dipromosikan sebagai potensi wisata budaya dengan tetap menjaga nilai-nilai luhur di dalamnya. Dan ketiga kepada para akademisi hendaknya mampu menggali nilai-nilai kearifan lokal agar tidak hilang tergerus perkembangan jaman dan teknologi yang semakin maju. Tujuannya adalah agar pariwisata mampu memperkenalkan tidak saja hanya sebatas produk budaya, namun juga nilai-nilai luhur dalam kebudayaan tersebut. 
Dengan demikian, hubungan antara dunia pariwisata dengan kebudayaan mampu saling bersinergi dan saling menjaga eksistensi satu sama lain.

\section{DAFTAR PUSTAKA}

Arisanti, Nyoman. 2015. "Uang Kepeng Dalam Kehidupan Masyarakat Bali Kontemporer". Tesis Program Pascasarjana Universitas Udayana.Denpasar.

Astiti, Ni Komang Ayu. 2014. "Uang Kepeng Sepanjang Masa: Perspektif Arkeologi dan Ekonomi Kreatif di Provinsi Bali”, dalam Jurnal Ilmiah Forum Arkeologi, Volume 27, Nomor 1, April 2014.

Nurkancana, I Wayan. 2009. Menguak Tabir Perkembangan Hindu. Denpasar: Pustaka Bali Post.

Ritzer, George. 2014. Teori Sosiologi Modern. Jakarta: Kencana.

Suarka, I Nyoman. 2009. "Wacana "Sangkan-Paran” Dalam Kakawin Aji Palayon: Sebuah Analisis Semiotik", dalam Jurnal Linguistika: Buletin Ilmiah, September 2009, Program Magister Linguistik Universitas Udayana.

Sudarma, I Putu. 2016. Esensi Uang Kepeng dalam Upacara Ngaben di Bali. Surabaya. Paramita.

Sumadi, I Ketut. 2012. "Perkembangan Pariwisata Budaya di Kuta: Dari Desa Pelabuhan Sampai Global Tourism Village”, dalam Jurnal Vidya Duta, Volume 2, Maret, 2012, Fakultas Dharma Duta IHDN Denpasar.

Sumadi, I Ketut. 2012. "Bali Dan Pariwisata Dalam Perspektif Teori Hegemoni”, dalam Jurnal Pangkaja, Volume 13, Maret 2012, Program Pascasarjana IHDN Denpasar.

Wikarman, I Nyoman Singgih. 1998. Leluhur Orang Bali. Surabaya: Paramita. 